\title{
Implication of forest zonation on tree species composition, diversity and structure in Mabira Forest, Uganda
}

\author{
Elias C. Weldemariam ${ }^{1,2 *}$, Emmy S. Jakisa ${ }^{1}$, Diana A. Ahebwe ${ }^{1}$ \\ ${ }^{1}$ Makerere University, College of Agricultural and Environmental Sciences, Department of \\ Environmental Management: P.O. Box 7062, Kampala, Uganda \\ ${ }^{2}$ Amhara Agricultural Research Institute, Gondar Agricultural Research Centre, P. O. Box 1337, \\ Gondar, Ethiopia
}

Received: 28 September 2016

Accepted: 28 February 2017

Published online: 7 March 2017

\begin{abstract}
The study aimed to investigate effectiveness of forest management zoning in conserving biodiversity of Mabira forest reserve. The study sites buffer, production, and strict nature reserve management zones were purposively selected. This was undertaken through investigating woody species diversity, composition and structure. A total of 60 sampling plots with a size of $20 \mathrm{~m} \times 10 \mathrm{~m}$ were used to collect vegetation data. Variables such as woody plant species identification and counts as well as diameter at breast height (DBH) of trees were done. The result depicted a total of 65 woody species; 39 in buffer, 19 in productions and 37 in strict nature reserve. Of these, only 9 trees species were found common to all zones and their Sorensen similarity coefficient was 0.2213 . The population structure of the buffer and strict nature reserve zones was found to be a $\mathbf{J}$ - shape pattern, whereas the production zone shown an inverted J-shape pattern. Higher woody species diversity was depicted in the buffer and strict nature zones with $\left(\mathrm{H}^{\prime}=2.73512\right)$ and $\left(\mathrm{H}^{\prime}=2\right.$. $68412)$ respectively, and lower in a production zone $\left(H^{\prime}=1.63628\right)$. The evenness index value of a buffer zone was $(\mathrm{J}=0.746574)$, strict nature $(\mathrm{J}=0.743335)$ and production $(\mathrm{J}=0$. 555719). The production zone had shown higher IVI values followed by buffer and strict nature reserve zone. The most important woody species identified based on their IVI value were Broussonetia papyrifera (Production), Acalypha neptunica (Buffer), Funtumia Elastica (strict nature reserve). The existing forest management is effective in conserving the biodiversity of the forest reserve. Nevertheless, the production zone was still suffering from exploitation of the surrounding community, hence serve for protecting the remaining management zones from further human interference. Further investigation is also required on the adjacent community perceptions of the forest management zoning.
\end{abstract}

Keywords: composition, diversity, population structure, woody species, management zones, Mabira Forest Reserve

* Corresponding author: Elias C. Weldemariam

e-mail: eliachent@gmail.com 


\section{Introduction}

Significant extent of tropical rain forests has been destroyed through deforestation and degradation, leading to loss of biodiversity (Lawer et al. 2013; Putz and Redford 2010) and destabilizing the forests structures(Carreño-Rocabado et al. 2012). Biodiversity fosters the functioning and stability of forest ecosystems and, consequently, the provision of crucial ecosystem services that support human well-being and quality of life (Pedro et al. 2015). Hence, the urgent need for interventions to restore and maintain forest biodiversity and ecological functioning (Lamb et al. 2005).

Forest management strategy like forest zonation has been adopted as means to protect the ongoing degradation of the intact forests. In Uganda, forest zoning is practiced in forests reserves like Mabira. Mabira forest reserve (MFR) is categorized as a protected area of core conservation values. The forest is a central forest reserve relatively rich in biodiversity and ecologically important forest species(Howard 1991). It provides habitat for different faunas and flora; and is also a home for some endemic tree species in Uganda (Fungo et al. 2013). Over the years, Mabira forest reserve has been subjected to multiple threats to its status (Devine 2004), within and outside the protected forest boundaries. The forest is flanked by tea and sugar plantations and factories, and has several enclave communities within its boundaries (Devine 2004), all of which extract resources like timber and firewood from the forest, imposing enormous pressures on it. Consequently, the forest has been degraded, calling for a new management strategy (Bahati et al. 2008).

Zoning of the forest has been adopted as a management strategy of MFR. According to Haas et al. (1987), this management strategy gives clear, specific, and effective management directions and minimizes conflicts between forest users (Zhang 2005). It allows maintaining the forest ecosystem condition while providing products and services to forest users (Côté et al. 2010). Thus, the forest zoning strategy allows for comprehensive conservation of the forest, particularly its tree species diversity, composition, and structure. For the forest zoning purpose, the forest was subdivided into three zones; a strict nature reserve, buffer zone and production zone (Nabanoga et al. 2010). In the strict nature reserve, no extractive use is allowed, except where research activities are conducted, but even then, removal of material such as plant is strictly restricted (Fungo et al. 2013). The Buffer zone has activities such as ecotourism and harvesting of limited plant material for medicinal purposes by local communities (Fungo et al., 2013). The production zone is one where harvesting trees for timber are permitted (Fungo et al. 2013).

However, although the aim at zoning of Mabira forest was to conserve and enhance its biodiversity and ecological conditions, the status of the forest, particularly its biodiversity is still being adversely affected (Obua et al. 2010). Therefore, there is a need to determine the effectiveness of the forest zoning in order to provide information about the forest conservation status and explore on sustainable management strategies. Currently, information on the effectiveness of the management zones is lacking. Thus this study aimed at assessing the effectiveness of forest management zones for tree species diversity, composition, and structural conservation of Mabira forest reserve.

\section{Study area and methods}

\subsection{Study area}

The study was conducted in Mabira forest reserve (figure1). It is a tropical rain forest located in South Central Uganda between $0^{\circ} 22^{\prime}-0^{\circ} 35^{\prime} \mathrm{N}$ and $32^{\circ} 56^{\prime}-33^{\circ} 02^{\prime} \mathrm{E}$. The forest covers an area of $306 \mathrm{~km}^{2}$ (31,293 ha) traversing Mukono and Kayunga districts of Uganda (Fungo et al. 2013). The forest is a medium altitude forest, located between 1070 and $1340 \mathrm{~m}$ above sea level, occupying gently undulating plains with numerous flat-topped hills and wide shallow valleys (Fungo et al. 2013). The reserve is isolated from other protected areas by agricultural land. 
The area is characterized by ferritic soil type of texture ranging from loamy to sandy clay loams with isolated cases of waterlogged clays in the valley bottoms(AES 2001). The climate in and around the forest is tropical humid with bimodal rainfall from March to June and September to November for the long and short duration rains respectively with annual mean precipitation ranging between 1250 and $1400 \mathrm{~mm}$. The annual mean minimum and maximum temperatures range between $16^{\circ} \mathrm{C}$ to $17^{\circ} \mathrm{C}$ and $28^{\circ} \mathrm{C}$ to $29^{\circ} \mathrm{C}$, respectively.

The forest has a dense undergrowth of various shrubs, lianas, climbers and herbs with a closed canopy. It is rich in biota harbouring $47 \%$ of Uganda's total plant species including 151 species of forest birds, 2 species of diurnal forest primates, 39 species of forest swallow tail and 218 species of butterflies. Many of these are on the list of globally endangered species (Baranga 2007). According to Lung and Schaab (2004), the population density within $2 \mathrm{~km}$ of Mabira forest reserve in 2002 was 302 inhabitants $/ \mathrm{km}^{2}$. Within MFR, there are also 27 villages (Baranga 2007), commonly known as enclaves, where subsistence farming is the primary activity for the 3,506 families within. The most commonly grown crops are maize, cassava, bananas, sugarcane and beans. A large section of the community is involved in some illegal activities like charcoal burning, pit sawing and collection of poles for construction as well as collecting medicinal plants mainly for their local use. The forest reserve receives more than $62 \%$ of all tourists visiting the country.

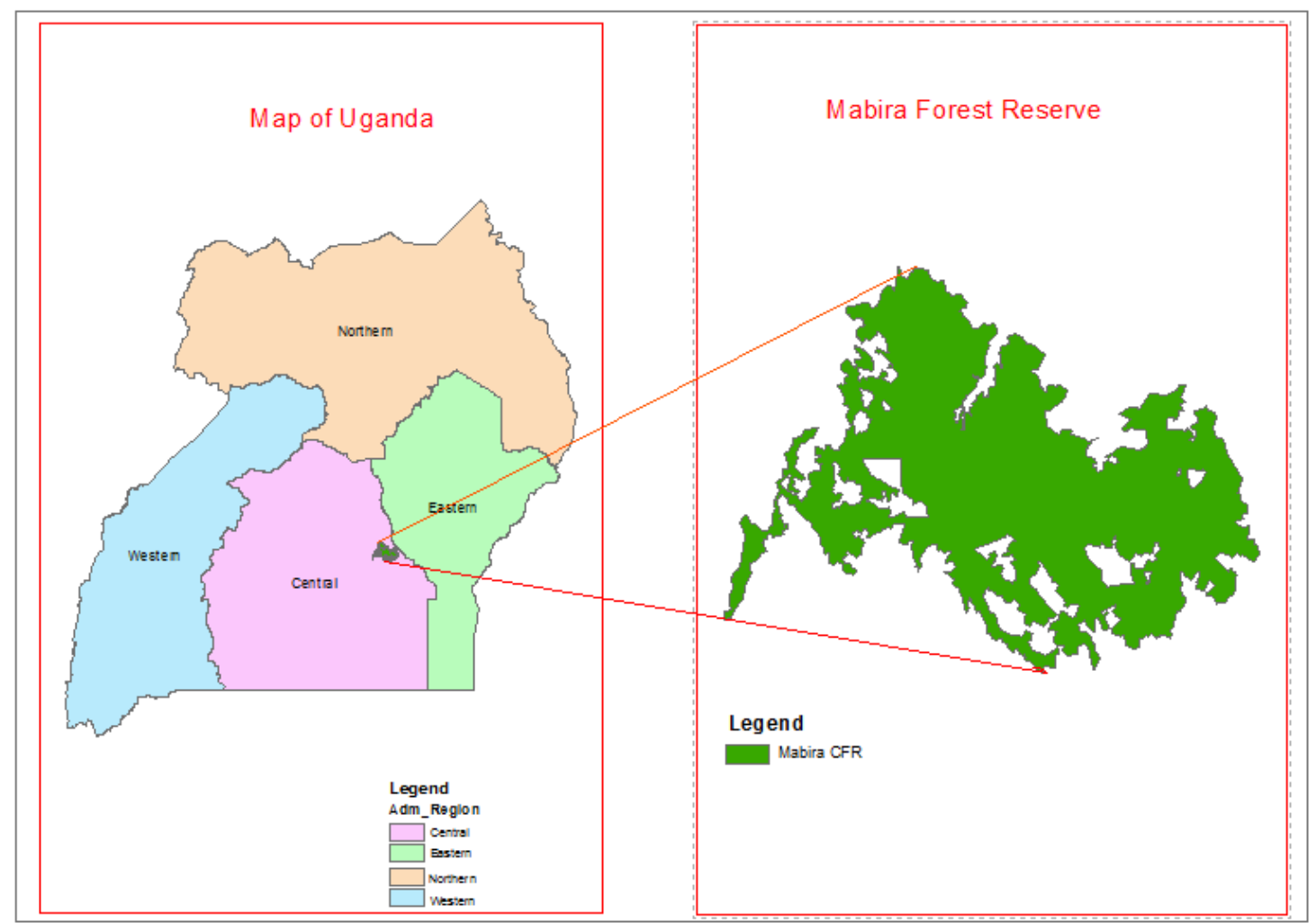

Fig. 1 Study area map.

\subsection{Field methods}

All the required data used as input in this research was collected from the end of Januray and to mid February 2014. Prior to the establishment of the sampling plots, a reconnaissance survey was done to select the best way and route for laying a transects. Two transects in each management zone were established following the procedures(Kent and Coker 1992). Each transect in the forest zone was $500 \mathrm{~m}$ long. Ten plots were alternately laid on each transect. The orientation of the transect line was NS direction and this was done by using a compass traverse. The distance between two consecutive plots 
was $50 \mathrm{~m}$. A total of 60 sample plots were laid in the study area. The systematic sampling method was employed to collect the data. To avoid the edge effects the first plot was established by measuring $50 \mathrm{~m}$ away from the edge of the forest. Following Eilu \& Obua (2005) the main study plots was $20 \mathrm{~m} \times 10$ $\mathrm{m}$ (Fig. 2). The plots were nested into $10 \mathrm{~m} \times 10 \mathrm{~m}, 10 \mathrm{mx} 5 \mathrm{~m}$, and $5 \mathrm{~m} \times 5 \mathrm{~m}$ plot size (Alder and Synnott 1992). In the $20 \times 10 \mathrm{~m}$ plot, tree species of diameter at breast height (dbh) $\geq 20 \mathrm{~cm}$ were sampled. In the $10 \times 10 \mathrm{~m}$ subplot, tree species of size class $10<20 \mathrm{~cm}$ dbh were identified, in the $5 \times$ $10 \mathrm{~m}$ subplot tree species of dbh $5<10 \mathrm{~cm}$ were identified and in a $5 \times 5 \mathrm{~m}$ subplot the size class $1<5$ $\mathrm{cm}$ dbh was sampled. The tree species sampled were identified, counted and their respective dbh were recorded.

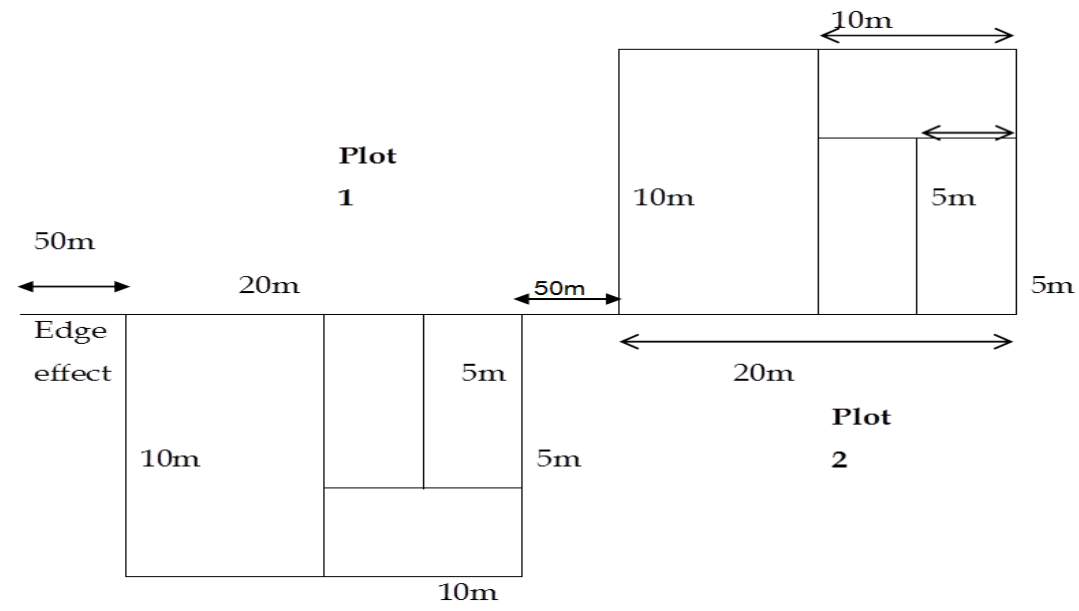

Fig. 2 Field sample plot layout.

Global Positioning System (GPS) coordinate for each sampling points were also collected. Other variables such as evidence of the state of human activities, canopy cover, undergrowth, different shrubs, lianas, climbers and herbs species were recorded in each transect with the help of field assistant. The ground covers abundance and canopy cover for each study plots were estimated by using visual eye judgment.

\subsection{Methods of data analysis}

The collected data was compiled entered, cleaned and analysed using MS excel sofware. To compare the woody species successional stage of each management zones a combined population structure using frequency histograms for each identified diameter class distribution following Peters (1996) was obtained. Species abundance for each management zones was computed using excel window.

The tree species richness (the number of species) was determined by summing up the number of species identified within each management zone. Shannon-Weiner diversity index was used to quantify woody species diversity and evenness index. Shannon-Wiener diversity index accounts both for species richness and evenness, and it is not affected by sample size(Kent and Coker 1992). Species diversity and richness 4.1.2 software and excel windows were used to compute these variables.

\section{Shannon-Weiner diversity index and evenness index was calculated as follow:}

$$
H^{\prime}=-\sum_{i=1}^{S} p i l n p i \quad E q .1
$$

Where, $\mathrm{H}^{\prime}=$ Shannon diversity index, $\mathrm{S}=$ the number of species, $\mathrm{Pi}=$ the proportion of individuals or the abundance of the $\mathrm{i}^{\text {th }}$ species expressed as a proportion of total cover and $\ln =\log$ base $\mathrm{n}$. 
Evenness (Equitability) $\mathbf{J}=\mathbf{H}^{\prime} / \mathbf{H}^{\prime} \mathbf{m a x}$, where: $\mathbf{J}=$ Evenness, $\mathbf{H}^{\prime}=$ Shannon-Wiener diversity index and, H'max = lns where $\mathrm{s}$ is the number of species. The values of Shannon's diversity index, H', typically lie between 1.5 and 3.5, although in exceptional cases, they can exceed 4.5.

Importance Value Index (IVI) enables comparison of the ecological significance of species in a given forest type. IVI was calculated following (Roberts-Pichette \& Lynn, 1999):

$$
I V I=R D o m+R F+R D
$$

Where IVI is the importance value index; RD is relative density; RDom is relative dominance; RF is relative frequency.

The Sorensen similarity coefficient was computed to compare the existing similarity between woody species in the three management zones. Following Kent and Coker (1992), Sorensen coefficient of similarity ( $\mathrm{Ss}$ ) was calculated as follows: promptly

$$
\text { SS }=\frac{2 a}{2 a+b+c} \quad E q .3
$$

Where $\mathrm{Ss}=$ Sorensen similarity coefficient, $\mathrm{a}=$ number of species common to both samples, $\mathrm{b}=$ number of species in sample $1, \mathrm{c}=$ number of species in sample 2 .

\section{Results}

\subsection{Tree population structure}

The population diameter class distribution pattern of woody species depicted two diameter class distribution patterns. The first were inverted J-shape pattern of distribution in which the numbers of woody species in the lower diameter class were found to be higher than that of woody species at higher diameter class. The second pattern was a J- shape pattern of distribution where tree species at lower diameter class had shown a lower number of individuals. The overall diameter class distribution pattern revealed the production zone had inverted J-shape, whereas the buffer and strict nature reserve management zones had shown a J-shape pattern of diameter class distribution (Fig. 3).

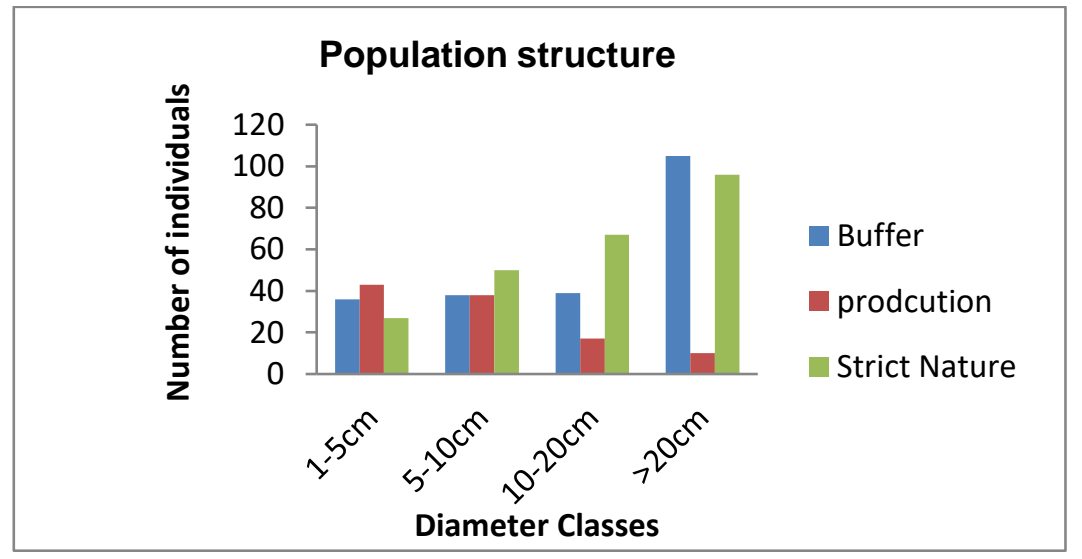

Fig. 3 Population structure of woody trees species in the management zones.

\subsection{Abundance, composition, and similarity of woody species}

A total of sixty-five woody species were identified in the three management zones. Of these, thirty-nine tree species were found in the buffer, nineteen in the production, and thirty-seven in the strict nature reserve management zone (Fig. 4). The overall tree species abundance of the strict nature reserve and buffer management zones was found to be higher than production zone (Fig. 4). The most abundant tree species identified in each management zone were given as follows; Broussonetia 
papyrifera(31.19\%),Funtumia elastica(7.79\%)., and Acalypha neptunica(7.79\%) in the buffer zone. Broussonetia papyrifera(62.96\%), Ficus exasperata(7.4\%) and ,Markhamia lutea(4.62\%) in the production zone. Funtumia elastica(31.25\%), Teclea nobilis(16.66\%) and Celtis Africana(8.33\%) was the most abundant woody species in the strict nature zone.

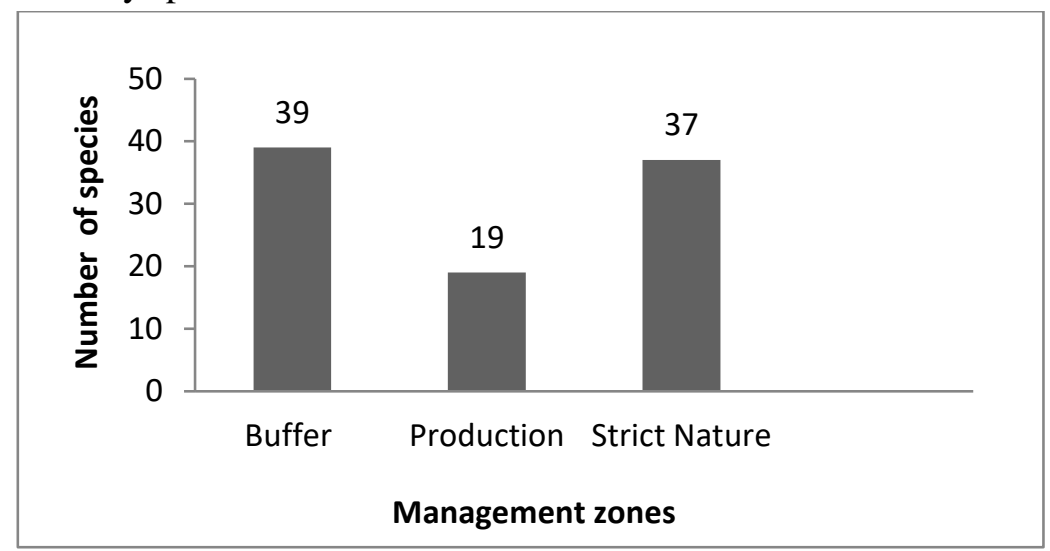

Fig. 4 Overall species composition of each management zone.

The Sorensen similarity coefficient was 0.2213 and this value indicated lower species similarity between the three management zones. Out of the sixty-five identified woody species, only nine tree species were found common to all management zones. Some of the commonly available woody species were; Antiaris toxicaria Lesch. , Broussonetia papyrifera, Celtis durandii, Coffea canephora, Ficus sur, Maesopsis eminii, Markhamia lutea, Teclea nobilis, and Trelipisium madagascariensis. Similarly, the production zone has a lower species abundance than the buffer and the strict nature reserve zones (Fig. 5).

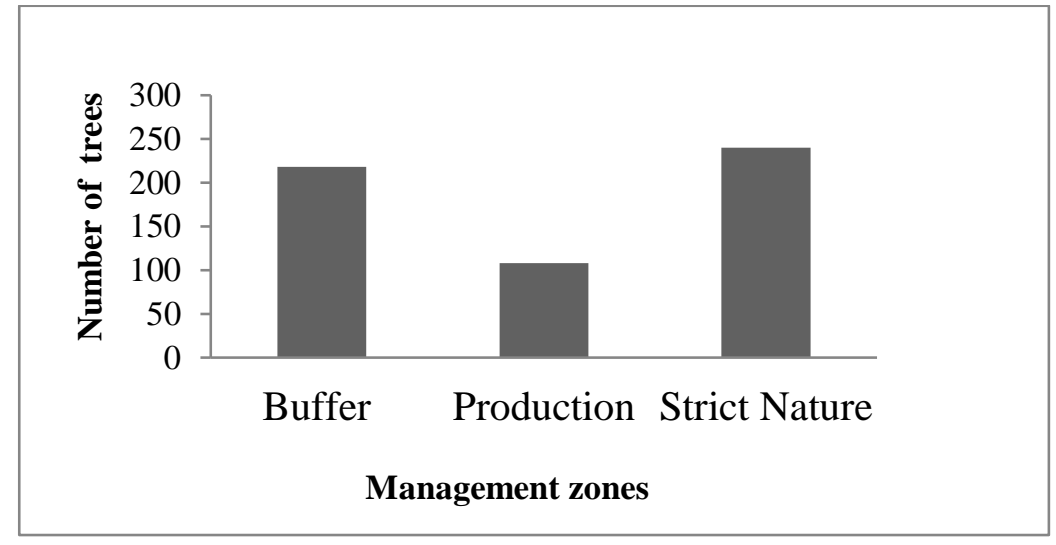

Fig. 5 Woody Species abundance of each management zone.

\subsection{Woody species diversity and evenness}

The wood species diversity and evenness indexes for each site were analyzed. The result revealed that among the three management zones, buffer and strict nature reserve zone had shown the highest species diversity index value of $\left(\mathrm{H}^{\prime}=2.73512\right)$ and $\left(\mathrm{H}^{\prime}=2.68412\right)$ respectively, and the lowest species diversity index was found in the production management zone $\left(\mathrm{H}^{\prime}=1.63628\right)$.

The species evenness index was higher for both buffer $(\mathrm{J}=0.746574$ and strict nature $(\mathrm{J}=0.743335)$ management zones and production management zone had shown relatively the least evenness value of $(\mathrm{J}=0.555719)$ (Tab. 1). The higher evenness values for buffer and the strict nature zone would indicate the even distribution of species in the sites as compared to the production zones. 
Tab. 1 Tree species diversity, evenness, and richness.

\begin{tabular}{cccc}
\hline & Buffer Zone & Production Zone & Strict Nature Zone \\
\hline Diversity & 2.735 & 1.636 & 2.684 \\
Evenness & 0.746 & 0.555 & 0.743 \\
Richness & 39 & 19 & 37 \\
\hline
\end{tabular}

\subsection{Importance Value Indices (IVI)}

Tab. 2 shows the most important woody species identified with the highest IVI value were Acalypha neptunica (62), Broussonetia papyrifera (38), Funtumia elastica (23) in the buffer zones. Broussonetia papyrifera (138), Artabotrys spp.(22), Ficus exasperata (17), Markhamia lutea(17) in the production zone. Funtumia elastica (56), Canthium vulgare( 38),Teclea nobilis (34) was the most important woody species found in the strict nature zone. Furthermore, the IVI value of less important tree species in each management zone was shown in Appendix 1.

Tab. 2 Woody species density, composition, and important value index of management zones.

\begin{tabular}{|c|c|c|c|c|c|c|c|c|c|}
\hline Species name & Family name & Zone & $\mathbf{A B}$ & D/ha & RD & RF & Rdom & IVI & IVIR \\
\hline Acalypha neptunica Müll.Arg. & Euphorbiaceae & $\mathrm{B}$ & 17 & 300 & 19 & 3 & 40 & 62 & 1 \\
\hline Blighia unijugata Baker. & Sapindaceae & $\mathrm{B}$ & 3 & 40 & 3 & 3 & 3 & 9 & 10 \\
\hline $\begin{array}{c}\text { Broussonetia papyrifera (L.) } \\
\text { L'Hér. ex Vent }\end{array}$ & Moraceae & $\mathrm{B}$ & 68 & 368 & 24 & 6 & 9 & 38 & 2 \\
\hline Celtis durandii Engl. & Ulmaceae & $\mathrm{B}$ & 4 & 63 & 4 & 3 & 4 & 11 & 8 \\
\hline Celtis africana N.L.Burm & Ulmaceae & $\mathrm{B}$ & 16 & 78 & 5 & 5 & 2 & 11 & 6 \\
\hline Celtis mildbraedii Engl. & Ulmaceae & $\mathrm{B}$ & 15 & 65 & 4 & 6 & 1 & 11 & 7 \\
\hline Coffea canephora. & Rubiaceae & $\mathrm{B}$ & 4 & 80 & 5 & 2 & 13 & 20 & 4 \\
\hline Funtumia elastica (Preuss) Stapf. & Apocynaceae & $\mathrm{B}$ & 17 & 170 & 11 & 6 & 6 & 23 & 3 \\
\hline Manicala spp & & $\mathrm{B}$ & 1 & 20 & 1.3 & 2 & 8 & 10 & 9 \\
\hline Markhamia lutea K. Schum . & Bignoniaceae & $\mathrm{B}$ & 10 & 40 & 3 & 5 & 0.9 & 8 & 11 \\
\hline Trilepisium madagascariensis & Moraceae & $\mathrm{B}$ & 12 & 68 & 4 & 6 & 1.4 & 12 & 5 \\
\hline Acalypha neptunica Müll.Arg. & Euphorbiaceae & $\mathrm{P}$ & 1 & 20 & 2 & 3 & 3 & 8 & 9 \\
\hline Antiaris toxicaria Lesch. & Moraceae & $\mathrm{P}$ & 3 & 45 & 3 & 6 & 2 & 12 & 5 \\
\hline Artabotrys spp. & Annonaceae & $\mathrm{P}$ & 3 & 60 & 4 & 3 & 15 & 22 & 2 \\
\hline $\begin{array}{c}\text { Broussonetia papyrifera (L.) } \\
\text { L'Hér. ex Vent }\end{array}$ & Moraceae & $\mathrm{P}$ & 68 & 935 & 69 & 9 & 60 & 138 & 1 \\
\hline Celtis durandii Engl. & Ulmaceae & $\mathrm{P}$ & 2 & 25 & 2 & 6 & 1 & 9 & 7 \\
\hline Ficus exasperata Vahl & Moraceae & $\mathrm{P}$ & 8 & 48 & 4 & 13 & 0.9 & 17 & 3 \\
\hline Ficus sur Forssk. & Moraceae & $\mathrm{P}$ & 3 & 18 & 1.3 & 9 & 0.4 & 11 & 6 \\
\hline Margaritaria discoidea (Baill.) & Euphorbiaceae & $\mathrm{P}$ & 1 & 20 & 2 & 3 & 4 & 9 & 8 \\
\hline Markhamia lutea K. Schum . & Bignoniaceae & $\mathrm{P}$ & 5 & 55 & 4 & 9 & 3 & 17 & 4 \\
\hline Trelipisium madagascariensis & Moraceae & $\mathrm{P}$ & 2 & 15 & 1.1 & 6 & 0.5 & 8 & 10 \\
\hline $\begin{array}{c}\text { Broussonetia papyrifera (L.) } \\
\text { L'Hér. ex Vent }\end{array}$ & Moraceae & SNR & 9 & 75 & 5 & 6 & 3 & 13 & 5 \\
\hline Canthium vulgare & Rubiaceae & SNR & 11 & 165 & 10 & 4 & 24 & 38 & 2 \\
\hline Celtis africana N.L.Burm & Ulmaceae & SNR & 20 & 128 & 8 & 6 & 5 & 19 & 4 \\
\hline Celtis mildbraedii Engl. & Ulmaceae & SNR & 11 & 53 & 3 & 4 & 1.2 & 9 & 8 \\
\hline Celtis wightii Planch. & Ulmaceae & SNR & 6 & 45 & 3 & 6 & 2 & 11 & 7 \\
\hline Chrysophyllum albidum G. Don & Sapotaceae & SNR & 2 & 30 & 2 & 3 & 3 & 8 & 10 \\
\hline $\begin{array}{c}\text { Entandrophragma angolense } \\
\text { (Welw.) }\end{array}$ & Meliaceae & SNR & 6 & 50 & 3 & 3 & 2 & 8 & 9 \\
\hline
\end{tabular}




\begin{tabular}{cccccccccc}
\hline Species name & Family name & Zone & AB & D/ha & RD & RF & Rdom & IVI & IVIR \\
\hline Funtumia elastica (Preuss) Stapf. & Apocynaceae & SNR & 75 & 470 & 29 & 6 & 21 & 56 & 1 \\
Teclea nobilis Hook. f . ex Oliver & Rutaceae & SNR & 28 & 223 & 14 & 6 & 15 & 34 & 3 \\
Trilepisium madagascariensis & Moraceae & SNR & 17 & 88 & 5 & 4 & 3 & 13 & 6 \\
\hline
\end{tabular}

Only the 10 most abundant tree species in each management zone were presented. Legend: $\mathrm{B}=\mathrm{Buffer}$ zone, $\mathrm{P}=$ Production zone, $\mathrm{SNR}=$ Strict Nature Reserve Zone, $\mathrm{AB}=\mathrm{Abundance}, \mathrm{D} / \mathrm{h}=$ =Density per hectare, $\mathrm{RD}=$ Relative Density, $\mathrm{RF}=\mathrm{Relative}$ Frequency, Rdom= Relative Dominance, IVI= Important Value Index, IVI R=Important Value index Rank

\section{Discussion}

Information on the population structure of a tree species would indicate the history of past disturbance of the species taken into consideration and its associated environment, which can also be used to forecast the future trend of the population of particular species (Bekele 1994; Teketay 1997).The population structure of the production zone was found to be a typical inverted J-shape distribution pattern. This indicated a good seedling recruitment and sapling development potential which is important for future population self-maintenance of the forest reserve. This result is in agreement with a related study done by (Okiror et al. 2012). The presence of less mature trees (i.e. <20dbh) in this zone was due to the problem of disturbance whereby the matured trees were removed for the purpose of charcoal burning, fuel wood collection, fruit collection and timber harvesting (personal observation of the site). According to , Chapman et al. (1997) and Whitmore and Sayer (1992) disturbance through uncontrolled logging were considered as the main factors destroying mature and young trees. However, the buffer and strict nature reserve zone, dipcted the highest distribution of mature trees than younger saplings and seedlings trees. The population diameter class size distribution pattern in this management zone showed J-shape pattern. As it was shown in Peters (1996)a J-shaped pattern of distribution indicates the precence of severe limitation in the newly regenerating seedlings and sapling trees. This could be linked to many factors like anthropogenic and natural fctors. Such a condition also could have been resulted from little canopy opening that affecting undergrowth and regeneration. According to Laughlin et al. (2005) and Giliba et al. (2011),one of the factors associated with this difference in population structure could be anthropogenic activities. Similarly, frequent human interference could lead in disturbing the ecosystem, community, or population structure and changes resources availability(Chapman et al. 1997; Pickett and White 1999).

Our study sought Broussonetia papyrifera as the most abundant tree species depicted in the two management zones namely buffers and production zone. The dominancy of these zone by this tree species might be becouse of its its growth habits and its potential to tolerate diverse environmental condition. Similarlly, Winterbottom and Eilu (2006) and Nabanoga et al. (2010) reported Broussonetia papyrifera as the most dominant colonizing understory species within Mabira central forest reserve. Furthermore, Bahati et al. (2008) also reported a 30\% cover abundance MFR by this tree species. Broussonetia papyrifera tree species has a tendency towards hampering the abundance of other indigenous broadleaf species growing in association with it (Bosu et al., 2013), hence can be considered as an invasive species.

The strict nature reserve had the highest species abundance followed by the buffer zone while the production zone has least species abundance. However, the species composition of the buffer zone was relatively higher followed by the strict nature and production zone. The higher abundance and composition of the two management zones was related to the current management practices they are receiving. The disturbance level and the management practices resulted in the varation of species composition and abundance in each maanagament zones.

Our result revealed the buffer and strict nature reserve had shown the highest species diversity index than the production management zone. The higher diversity index can tell us an even representation of individuals species in each sampling plots. Furthermore, this can be due to less 
disturbance activities in the other two zones than the production zone. Our result also agree with a study done by Lalfakawma et al. (2009) whereby undisturbed stand showed higher species diversity as compared to disturbed stands. The low woody species diversity obtained from the production zone could be due to the excessive wood harvesting practice exhibited by the local community; as evidenced we visualized charcoal burning activities carried out in this zone (personal observation). Laughlin et al. (2005)studied the effect of various types of disturbance on species diversity and had investigated their negative implication on species diversity. The higher evenness index value obtained from the strict nature zone and buffer zone indicated an even distribution of species in this management zone. Conversely, the low evenness index in the production zone suggests the dominancy of this area by a single tree species like Broussonetia papyrifera covered $62.96 \%$ of the total surveyed area in this zone compared to the other associated tree species. This result is ingreement with that of (Bahati et al. 2008).

The importance value index (IVI) is an aggregate index that summarizes the density, abundance, and distribution of a species(Okiror et al. 2012). This reflects the degree of dominance and abundance of a given species in relation to other species (Giliba et al. 2011; Kent and Coker 1992). Similarlly, IVI can give as an indication of the ecological significance of a species in the site (Muthuramkumar \& Parthasarathy, 2000). Wider variation in IVI was dipcted in the production management zone and this shows the different ecological importance of the species in the area. However, the IVI value of tree species in the strict nature management zone was relatively narrow. This implies the less dominancy of the area by a few tree species and showing equally are equally important. As described in Simon \& Girma (2004) and Worku (2007), a species with the highest dominance indices is considered as most important species in the area. Likewise, Acalypha neptunica, Broussonetia papyrifera and Funtumia elastica tree species were dipicted as the important tree species in each management zones. Similarly, woody species with highest abundance and density had shown to be the most important trees species in all management zones (Tab. 2). The dominance of these tree species could have been due to their growth habits and their ability to withstand harsh conditions (Wright 2002).

Overall, the forest management zones are serving their purposes. The strict nature reserve is protecting species disturbance and stopping species invasion conversely, the buffer zone has signs of disturbance, however the level of disturbance was less when compared to the production zone. In the absence of the buffer zone, degradation of the strict nature reserve would have been faster. The production zone is performing its task of allowing people to exploit forest products and preventing people from accessing the other zones. Nevertheless, this zone was found to have less of mature trees, biodiversity, and composition than the Buffer and Strict nature reserve zones as a result of large trees overharvesting practice. Further research should be done on how the abundant tree species behave in association with the other rare/less abundant tree species in the forest reserve. Management should find a way of making the Production zone self-sustaining as over-harvesting can prove a threat to it. Moreover, management should also find out a way of eliminating invasive species like Broussonetia papyrifer and limit its distbution over the reserve. Research has to be done on the less abundant tree species to find out how to improve their abundance. Since this study only focused on assessing the vegetation status further investigation has to be done on the adjacent communities' perception of the zoning. There is also a need of strengthening the existing regulations to reduce the rate of encroachment activities done by the surrounding community, especially in the production zone.

\section{Acknowledgements}

Our sincere appreciation goes to biodiversity field groups: Miss. Judith Nyiramugisha, Mr. Topher Arinaitwe, and Mr. Joseph Mbihayeimaana for their great contribution and effort in field data collection. Likewise, we thank Miss. Antonia Nyamukuru for helping with data collection and continuous guidance throughout this study. To Associate Prof.Vincent Mwanika for mobilizing the 
funds, making necessary logistics arrangements that enabled us to go to the field and guiding us throughout this study. We also thank Prof. John R.S. Tabuti for his constructive comments that improved our write up. Further appreciation also goes to Mr. Cory for helping us in the field data collection and for his valuable comments. Finally, the contribution to Mr. Robert, Mr. Ali, and Mr. Dawo was unforgettable for their enthusiastic support in identification of tree species and guiding us while we were in the forest. Our special thanks also go to Makerere University, Department of Environment and Natural Resources for funding the fieldwork.

\section{References}

AES, NP (2001) Description of soils within the region, Appendix B1. Bujagali Project Transmission System, EIS.

Alder D and Synnott TJ (1992) Permanent sample plot techniques for mixed tropical forest. London: Oxford University Press,.

Bahati J, Banana AY, Gombya-Ssembajjwe W (2008) Assessing the impacts of decentralization on livelihood, biodiversity and ecological sustainability in Uganda: A preliminary analysis of the pilot SANREM/IFRI site.

Baranga D (2007) Observations on resource use in Mabira Forest Reserve, Uganda. African Journal of Ecology, 45(s1), 2-6.

Bekele T (1994) Studies on remnant Afromontane forests on the central plateau of Shewa, Ethiopia, Uppsala Univ.

Bosu PP, Apetorgbor MM, Nkrumah EE, Bandoh KP (2013) The impact of Broussonetia papyrifera (L.) vent. on community characteristics in the forest and forest-savannah transition ecosystems of Ghana. African Journal of Ecology, 51(4), 528-535.

Carreño-Rocabado G, Peña-Claros M, Bongers F, Alarcón A, Licona, J-C, Poorter L (2012) Effects of disturbance intensity on species and functional diversity in a tropical forest. Journal of Ecology, 100(6), 1453-1463.

Chapman CA., Chapman LJ, Wrangham R, Isabirye-basuta G, Ben-david K (1997) Spatial and temporal variability in the structure of a tropical forest. African Journal of Ecology, 35(4), 287-302.

Côté P, Tittler R, Messier C, Kneeshaw DD, Fall A, Fortin M-J (2010) Comparing different forest zoning options for landscape-scale management of the boreal forest: Possible benefits of the TRIAD. Forest Ecology and Management, 259(3), 418-427.

Devine MW (2004) Three Communities, Two Corporations, One Forest: Forest Resource Use and Conflict, Mabira Forest, Uganda.

Eilu $\mathrm{G}$ and Obua $\mathrm{J}$ (2005) Tree condition and natural regeneration in disturbed sites of Bwindi Impenetrable Forest National Park, southwestern Uganda. Tropical Ecology, 46(1), 99-111.

Fungo B, Eilu G, Tweheyo M, Baranga D (2013) Forest disturbance and cropping mixtures influence crop raiding by red-tailed monkey and grey-cheeked mangabey around Mabira Forest Reserve, Uganda. Journal of Ecology and The Natural Environment, 5(2), 14-23.

Giliba RA, Boon EK, Kayombo CJ, Musamba EB, Kashindye AM, Shayo PF (2011) Species Composition, Richness and Diversity in Miombo Woodland of Bereku Forest Reserve, Tanzania, 2(1).

Haas GE, Driver BL, Brown PJ, Lucas RG (1987) Wilderness Management Zoning., 85(12), 17-21.

Howard PC (1991) Nature Conservation in Uganda's Tropical Forest Reserves. IUCN, Gland, Switzerland and Cambridge,UK.xvii +313 pp.

Kent M and Coker P (1992) Vegetation description and analysis: a practical approach - Ghent University Library. London: Belhaven press.

Lalfakawma, Sahoo UK, Roy S, K Vanlalhriatpuia, Vanalalhluna PC (2009) Community Composition and Tree Population Structure in Undisturbed and Disturbed Tropical Semi Evergreen Forest Stands of North- East India.

Lamb D, Erskine PD, Parrotta J A(2005) Restoration of degraded tropical forest landscapes. Science (New York, N.Y.), 310(5754), 1628-32.

Laughlin DC, Bakker JD, Fule PZ (2005) Understorey plant community structure in lower montane and subalpine forests, Grand Canyon National Park, USA. Journal of Biogeography, 32(12), 2083-2102. 
Lawer EA, Baatuuwie BN, Ochire-Boadu K, Asante WJ, Lawer EA, Baatuuwie BN(2013) Preliminary Assessment of the Effects of Anthropogenic Activities on Vegetation Cover and Natural Regeneration in a Moist Semi-Deciduous Forest of Ghana. International Journal of Ecosystem, 3(5), $148-156$.

Lung T and Schaab G (2004) Change-detection in Western Kenya: the documentation of fragmentation and disturbance for Kakamega Forest and associated forest areas by means of remotely-sensed imagery.

Muthuramkumar S and Parthasarathy N (2000) Alpha diversity of lianas in a tropical evergreen forest in the Anamalais, Western Ghats, India. Diversity Distributions, 6(1), 1-14.

Nabanoga G, Namaalwa J, Ssenyonjo E (2010) REDD Working Papers: REDD and sustainable development - perspective from Uganda IIED. London.

Obua J, Agea JG, Ogwal JJ (2010) Status of forests in Uganda. African Journal of Ecology, 48(4), 853859.

Okiror P, ChonoJ, Nyamukuru A, Lwanga JS, Sasira P, Diogo P, Diogo P (2012) Variation in Woody Species Abundance and Distribution in and around Kibale National Park, Uganda. ISRN Forestry, 2012, 1-9.

Peters CM (1996) Observations on the sustainable exploitation of non-timber tropical forest products. Current Issues in Nontimber Forest Products Research, 19-39.

Pickett ST and White P (1999) The Ecology of natural disturbance and patch dynamics. Academic Press, New York, USA.

Putz FE and Redford KH (2010) The Importance of Defining "Forest": Tropical Forest Degradation, Deforestation, Long-term Phase Shifts, and Further Transitions. Biotropica, 42(1), 10-20.

Roberts-Pichette P and Lynn G (1999) Terrestrial vegetation biodiversity monitoring protocols. EMAN Occasional Paper Series, Report No. 9. Ecological Monitoring Coordinating Office. Burlington, Ontario.

Silva Pedro M, Rammer W, Seid R (2015) Tree species diversity mitigates disturbance impacts on the forest carbon cycle. Oecologia, 177(3), 619-630.

Simon S and Girma B (2004) Composition, structure and regeneration status of woody species in Dindin natural forest, Southeast Ethiopia: an implication for conservation, 3(1), 15-35

Teketay D (1997) Seedling populations and regeneration of woody species in dry Afromontane forests of Ethiopia. Forest Ecology and Management, 98(2), 149-165.

Whitmore TC and Sayer J(1992) Tropical Deforestation and Species Extinction (xvii +). Chapman \& Hall,London.

Winterbottom B and Eilu G (2006) UGANDA Biodiversity and Tropical Forest Assessment Report.

Worku A (2007) Population Status and Socio-economic Importance of Gum and Resin Bearing Species in Borana Lowlands, southern Ethiopia(Msc. Thesis). Addis ababa, ethiopia: addis ababa university, pp. $30-55$.

Wright JS (2002) Plant diversity in tropical forests: a review of mechanisms of species coexistence. Oecologia, 130(1), 1-14.

Zhang Y (2005) Multiple-use forestry vs. forestland-use specialization revisited. Forest Policy and Economics, 7(2), 143-156. 